\title{
Animal and plant-based milk and their antioxidant properties
}

\author{
Ayşe Arzu YİĞİT
}

Kırıkkale University, Faculty of Veterinary Medicine, Department of Physiology, 71450, Kırıkale/TURKEY

\begin{abstract}
Key Words:
almond milk

camel milk

cow milk

donkey milk

soy milk

ABSTRACT

Today, the most consumed milk is cow milk, which can be found in the market as raw, pasteurized and sterilized. In addition, goat and sheep milks are the milk types that are able to be reached easily. Nowadays, donkey and camel milk are also started to be demanded, due to its similarity to breast milk and due to many protective factors. As the rate of allergy development in the newborns and the tendency of vegan nutrition increased, the production of herbal milk began to increase as an alternative to animal milk. Besides the nutritious content of milk since it contains proteins, fats, carbohydrate and minerals, the antioxidant role of it also needed to be considered. With this advantage, human and camel

Anahtar Kelimeler:

badem sütü

deve sütü

inek sütü

eșek sütü milk became more prominent than th eother milk types. In this review, the nutritional and protective properties of milk were explained by taking attention to the composition of different milk types.
\end{abstract}

soya sütü

Received: 03.04.2019

Accepted: 03.09.2019

Published Online: 31.12.2019

Article Code: 549028

\section{Hayvansal ve bitkisel kaynaklı sütler ve antioksidan özellikleri}

Correspondence:

AA. YIĞìT

(aarzuyigit@kku.edu.tr)

ORCID:

\section{ÖZ}

Günümüzde tüketilen sütlerin çok büyük bir kısmı inek sütü olup, bunu da piyasada çiğ, pastörize ve sterilize olarak bulmak mümkündür. Ayrıca keçi ve koyun sütü de ulaşılabilmesi kolay olan sütlerdir. Bunların yanı sıra anne sütüne benzerliğinden ve pek çok koruyucu faktörü içermesinden dolayı eşek sütü ve deve sütü de son zamanlarda talep edilmeye başlanan sütler olmuştur. Yeni doğanlarda hayvansal sütlere karşı alerji gelişme oranı ve vegan beslenme eğilimi arttıkça hayvansal sütlere alternatif olarak bitkisel süt üretimi de artmaya başlamıştır. Süt, içerdiği protein, yăg, karbonhidrat, vitamin ve minerallerden dolayı besleyici bir besin olmasının yanısıra antioksidan rolü ile de göz ardı edilemeyecek bir içecektir. Bu yönüyle insan ve deve sütü diğer süt türlerinden daha öne çıkmaktadır. Bu derlemede farklı türlere ait sütlerin bileşimine dikkat çekilerek, sütün besleyici ve koruyucu özellikleri açıklanmıştır.

\section{INTRODUCTION}

Milk is secreted from mammalian mammary glands and it is rich in terms of protein, fat, and lactose content. Nowadays even though, the mostly consumed milk is the cow milk; goat, sheep, and buffalo milks are also sold on the market. In addition to these casein-rich milks, the popularity of the albumin-rich milks such as donkey, horse, and camel milks has been increased recently. However, the albumin-rich milks are not mostly available and quite expensive as compared to the others. Besides, the pasteurized form of albumin-rich milk has not been sold in the market yet in our country. Additionally, there are also pasteurized milks obtained from plant sources such as rice, soybean, almond, hazelnut, and coconut which are preferred by vegans and are preferred by the people with lactose tolerance. This review aims to reveal the nutritious and protective properties of different milk types by taking attention to their composition.

\section{ANIMAL MILK}

Derived from milk glands of mammals such as cows, sheep, goats, buffalos, donkeys, horses and camels, are named animal milk. Although the production and consumption of the first three ruminants' milks are the highest, the mare and donkey milks have been started to preferred recently in terms of higher lactose and lower fat, with higher omega 3 and omega 6 fatty acids (FAs) content than the ruminants' milk. Also, they have been preferred because of the similarity of the breast milk composition (1) (Table 2.1).

Table 2.1. Comparison of the mare, donkey, camel, cow and buffalo milk with breast milk in terms of some ingredients $(\mathrm{g} / 100 \mathrm{ml})$

$\begin{array}{llllll}\text { Breast } & \text { Mare } & \text { Donkey } & \text { C a m e l } & \text { Cow } & \text { Buffalo } \\ \text { milk } & \text { milk } & \text { milk } & \text { milk } & \text { milk } & \text { milk }\end{array}$

$\begin{array}{llllll}\text { (a) } & \text { (b) } & \text { (c) } & \text { (d) } & \text { (d) }\end{array}$

\begin{tabular}{lllllll}
\hline Lactose & 7.2 & 6.37 & 6.88 & 3.3 & $4.80-4.9$ & $4.5-5.0$ \\
Fat & 3.6 & 1.21 & 0.38 & $2.9-5.4$ & $3.7-4.4$ & $7-11.5$ \\
Protein & 1.4 & 2.14 & 1.72 & $3-3.9$ & $3-3.9$ & $3.3-3.6$ \\
\hline
\end{tabular}

a: 2 , b: 3 c: $1, d: 4$

\subsection{COMPOSITION OF THE ANIMAL MILK}

Milk is essential in terms of rich sources of calcium, 
phosphorus, and riboflavin (vitamin B2), vital amino acids and FAs. Although there are some other nutrients that contain these, lactose and milk proteins (casein, lactalbumin, and lactoglobulin), which increase the nutritional importance of milk, are found only in animal milk. However, it is quite difficult to give an exact composition of milk. Because, the milk composition depends primarily on the animal's species, and additionally depends on the amount of produced milk, the way of processing, the lactation period, mammary health, climatic conditions and nutrition (5) (Table 2.2, 2.3).

Table 2.2. Different components of pasteurized and UHT cow milk in different fat ratios (for $100 \mathrm{gr}$ of milk). (6)

\begin{tabular}{lccccc}
\hline Milk TypeS & $\begin{array}{c}\text { Energy } \\
(\mathrm{kcal})\end{array}$ & $\begin{array}{c}\text { Water } \\
(\mathrm{G})\end{array}$ & $\begin{array}{c}\text { CHO } \\
(\mathrm{G})\end{array}$ & $\begin{array}{c}\text { Fat } \\
(\mathrm{G})\end{array}$ & $\begin{array}{c}\text { Protein } \\
(\mathrm{G})\end{array}$ \\
\hline Whole, pasteurized & 63 & 87.6 & 4.6 & 3.6 & 3.4 \\
Whole, UHT & 66 & 90.2 & 4.8 & 3.9 & 3.2 \\
$\begin{array}{l}\text { Semi-skimmed, pas- } \\
\text { teurized }\end{array}$ & 46 & 89.4 & 4.7 & 1.7 & 3.5 \\
$\begin{array}{l}\text { Semi-skimmed,UHT } \\
\text { Skimmed, pasteurized }\end{array}$ & 46 & 90.9 & 4.9 & 1.6 & 3.3 \\
& 34 & 90.8 & 4.8 & 0.3 & 3.5 \\
Skimmed, UHT & 33 & 91.3 & 4.9 & 0.1 & 3.4 \\
\hline
\end{tabular}

Table 2.3. The changes in the composition of cow milk according in months $(\mathrm{kg} / \mathrm{hl})(7)$

\begin{tabular}{lccc}
\hline & Milk fat & Milk proteins & $\begin{array}{c}\text { Lactose and } \\
\text { other solids }\end{array}$ \\
\hline January & 3.99 & 3.34 & 5.71 \\
February & 4.00 & 3.32 & 5.72 \\
March & 4.01 & 3.34 & 5.73 \\
April & 3.97 & 3.30 & 5.74 \\
May & 3.91 & 3.27 & 5.71 \\
June & 3.85 & 3.24 & 5.73 \\
July & 3.77 & 3.20 & 5.72 \\
August & 3.78 & 3.25 & 5.70 \\
September & 3.92 & 3.33 & 5.70 \\
October & 4.04 & 3.37 & 5.70 \\
Nowember & 4.03 & 3.39 & 5.70 \\
December & 4.01 & 3.33 & 5.70 \\
\hline
\end{tabular}

\subsubsection{MILK PROTEINS}

Animal milk proteins made up of two main groups as $80 \%$ casein and 20\% serum (whey) proteins. Casein consist of $\alpha \mathrm{S} 1$ casein, $\alpha \mathrm{S} 2$ casein, $\beta$ casein, $x$ casein and $\gamma$ casein; serum proteins are mainly composed of lactoglobulin (LG) and lactalbumin (LA), serum albumin (SA), immunoglobulins (Ig), lactoferrin (LF), proteose-peptone 3 and ceruloplasmin (8) (Table 2.4).

Casein-protein ratio is at least $2 / 3$, as such in cow, sheep, and goat milk, are called as casein milk, and their most common fraction is $\alpha \mathrm{S} 1$. AlphaS1 casein is the type of casein which is the most common cause of milk protein allergy and it is not found in human milk. Milk with casein is resistant to high temperatures, but the casein precipitates in $\mathrm{pH} 4.6$, so it coagulates with acids, gastric secretions, and yeasts. This property of casein milk puts them to the class of hard digestible milk (8).

Serum proteins are the water-soluble proteins. Lactoglobulin has an immunologically protective role and it is found in casein milk with the highest rate, and the LA follows it with $20 \%$ percentage. If the total amount of albumin and globulin is more than $1 / 3$ of total protein, such as human, mare, donkey, dog and pig milk, this milk is called as albumin milk. Albumin milk is less resistant to high temperature than the casein milk. It also gives smaller granular and soft clot with acids, gastric secretions and yeasts, and it is easily digestible (Table 2.4). Approximately $35-50 \%$ of donkey milk proteins are composed of serum proteins such as $\alpha-\mathrm{LA}, \beta-\mathrm{LG}$, and $\operatorname{Ig}(5)$. However, human milk does not contain $\beta-L G$, that is the main serum protein of ruminant milk (9).

Lactoferrin is an iron-binding protein that forms the first line of defense against infections and inflammation and also it has an antiviral effect. Bovine serum albumin constitutes $8 \%$ of total milk proteins and it is useful in transport, metabolism, and protection against free radicals as in serum albumin (7). In addition, proteose-peptones, that composed of nitrogenous substances remaining in the serum, can be found in protein content about 3\% (10).

Besides, all these components, there are many enzymes in milk. One of them is alkaline phosphatase (ALP), that is a thermal indicator for pasteurization, is found in all mammalian milk. Although goat and mare milks have very small amounts of alkaline phosphatase, cow and sheep milks contain more. Since ALP is inactivated by thermal treatment, reduced levels of this enzyme shows the effectiveness of pasteurization. Xanthine oxidoreductase is the main protein and it has a protective role against fat globule membranes and its activity is the highest in cow milk. Plasmin is a proteolytic enzyme that is found higher in mare milk than cow milk (14).

Other protein fractions, such as immunoglobulins and growth factors also have beneficial effects on health. The mare, buffalo, and camel milks have higher Ig ratio than cow, sheep, goat and human milks. Immunoglobulins are the highest in colostrum milk and their level decrease during lactation. While $\operatorname{IgG}$ is high in mare and cow colostrum, IgA is high in mare milk and human colostrum and human mature milk. While pasteurization reduces the rate of Ig by 10 to $30 \%$, UHT technology significantly destroys the immunological protective 
Table 2. 4. Protein content of different animal milk types (Casein quantitiy is given as \%, the others are given as $\mathrm{g} / \mathrm{L}$ )

\begin{tabular}{|c|c|c|c|c|c|c|c|}
\hline Milk types & Cow & Buffalo & Sheep & Goat & Mare & Camel & Donkey \\
\hline Total protein & $32-35 \mathrm{a}$ & $36 \mathrm{~d}$ & $58 \mathrm{a}$ & $36 \mathrm{~g}$ & $21 \mathrm{c}$ & $18-32 \mathrm{i}$ & $15.7 \mathrm{k}$ \\
\hline Cazein & $24.6-28 \mathrm{~b}$ & $40 \mathrm{~d}$ & $41.8 \mathrm{f}$ & $2.81 \mathrm{~g}$ & $9.4-12 \mathrm{~b}$ & $2.65 j$ & $6.4-10.3 \mathrm{~b}$ \\
\hline Total whey proteins & $5.5-7 \mathrm{~b}$ & $6 \mathrm{e}$ & & $8.5 \mathrm{~g}$ & $7.4-9.1 \mathrm{~b}$ & $5.9-8.1 \mathrm{j}$ & $4.9-8 \mathrm{~b}$ \\
\hline$\beta-\mathrm{LG}$ & $3.2-3.3 \mathrm{c}$ & $3.9 \mathrm{e}$ & $6.5-8.5 \mathrm{e}$ & $1.5-5 \mathrm{c}$ & $2.55 \mathrm{c}$ & none & $1.3-5.51$ \\
\hline$\alpha-\mathrm{LA}$ & $1.2-1.3 \mathrm{c}$ & $1.4 \mathrm{e}$ & $1-1.9 \mathrm{e}$ & $0.7-2.3 \mathrm{c}$ & $3.37 \mathrm{c}$ & $0.8-3.5 \mathrm{j}$ & $0.8-2.71$ \\
\hline SA & $0.3-0.4 \mathrm{c}$ & $0.29 \mathrm{e}$ & $0.4-0.6 \mathrm{e}$ & & $0.37 \mathrm{e}$ & 7-11.9 j & 0.41 \\
\hline $\operatorname{Ig}$ & $0.5-1 \mathrm{c}$ & $10.66 \mathrm{e}$ & $0.7 \mathrm{e}$ & & $1.63 \mathrm{e}$ & $1.5-19.6 \mathrm{j}$ & 1.31 \\
\hline $\mathrm{LF}$ & $0.02-0.5 \mathrm{c}$ & $0.03-3.4 \mathrm{e}$ & $0.8 \mathrm{e}$ & $0.02-0.2 \mathrm{c}$ & $0.32 \mathrm{~h}$ & $0.02-7.28 \mathrm{j}$ & $0.005-0.051$ \\
\hline Lyzozyme & $(70-600) \times 10^{-6} \mathrm{c}$ & $120-152 \times 10^{-6} \mathrm{e}$ & $100 \times 10^{-6} \mathrm{e}$ & $250 \times 10^{-6} \mathrm{c}$ & $0.63 \mathrm{~h}$ & $60-1350) \times 10^{-6} j$ & $0.67-41$ \\
\hline
\end{tabular}

a: 6, b:11, c: 12, d: 13, e: 14, f: 15, g: 16, h: 17, i: 18, j: 19, k: 4, l: 1

activity of the milk (14).

Milk protein allergy is an allergy against some proteins usually found in cow milk. Studies have shown that the main cause of this allergy is an antibodies that is synthesized against $\alpha \mathrm{S} 1$ casein and $\beta$-LG (20). Infants and children that have an allergy to cow milk are likely to have an allergy to buffalo, goat, sheep, donkey and mare milks (9). Donkey milk is the most similar milk to human milk in terms of does not contain $\alpha \mathrm{S} 1$ casein and the differences of the $\beta$-LG structure (4). Camel milk do not include $\beta$-LG, however it contains more antibacterial agents such as lysozyme, LF, Igs, when compared to cow and buffalo milk (21). Goat milk has a low allergic feature due to the contains very low amount of $\alpha \mathrm{S} 1$ casein (20).

The nutritional value of the milk proteins is mainly dependent on their amino acids. Sheep and goat milks can be classified as the richest milk in terms of exogenous amino acids. Buffalo, cow, and mare milks have limited cysteine and methionine, while camel milk has limited lysine. Donkey milk has more valine and lysine than the other animal milk types. The contents of methionine, valine, phenylalanine, arginine, and leucine of camel milk are higher than of cow milk (11).

\subsubsection{MILK FAT}

Milk fat is composed of oil globules with diameter of 2-4 $\mu \mathrm{m}$. The triglyceride content of the fat globules changes by the seasonal ration changes, milk type, and lactation cycle. Moreover, the structure of the millk fat globules changes continuously from the secreted of the mammary glands until milking. The lipids of the milk fat globules consist of $98 \%$ tryglycerides, and short-chain FAs that have carbon number from 4 to 10. (22). While, short chain FAs are synthesized by de-novo in mammary tissue, long-chain FAs are synthesized from blood (7). The remaining part consists of $0.5-1.0 \%$ phospholipids, $0.2-0.5 \%$ free sterols, fat-soluble vitamins (A, D, E, K), free FAs, and FA derivatives (22). The mill in the market is sold as whole milk, low-fat milk and fat-free milk. The most critical factor in this classification is the milk FAs that is saturated or unsaturated (Table 2.5) (23).

As shown in table 2.6, goat milk is different from the cow milk since its fat can be easily digested and it has plenty of short-chain FA and small FA globules that facilitate the ab-
Table 2.5. Content of the fat, FA and cholesterol in cow milk (for $100 \mathrm{~g}$ milk) (23)

\begin{tabular}{|c|c|c|c|c|c|}
\hline Milk type & Kcal & $\begin{array}{l}\text { Saturated } \\
\text { FA (g) }\end{array}$ & $\begin{array}{l}\text { Monoun- } \\
\text { saturated } \\
\text { FA } \\
\text { (g) }\end{array}$ & $\begin{array}{c}\text { Polyun- } \\
\text { saturated } \\
\text { FA } \\
\text { (g) }\end{array}$ & $\begin{array}{c}\text { Choles- } \\
\text { terol } \\
(\mathrm{mg})\end{array}$ \\
\hline Whole (\% 3.3) & 61.5 & 2.09 & 0.98 & 0.12 & 13.53 \\
\hline $\begin{array}{l}\text { Semi-skimmed } \\
(\% 2)\end{array}$ & 49.5 & 1.19 & 0.57 & 0.08 & 7.38 \\
\hline $\begin{array}{l}\text { Semi-skimmed } \\
(\% 1)\end{array}$ & 41.8 & 0.66 & 0.29 & 0.04 & 4.10 \\
\hline Skimmed & 35.10 & 0.12 & 0.04 & trace & 1.63 \\
\hline
\end{tabular}

Table 2. 6. Fat and cholesterol contents of different animal milk types. Adapted from Barłowska et al. (28) and Salimei and Fantuz (24)

\begin{tabular}{|c|c|c|c|c|c|c|}
\hline & Buffalo & Sheep & Goat & Mare & Camel & Donkey \\
\hline 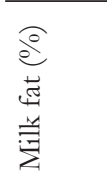 & $\begin{array}{l}4.90- \\
13.39\end{array}$ & $\begin{array}{r}4.10- \\
9.30\end{array}$ & $\begin{array}{r}3.06- \\
6.02\end{array}$ & $\begin{array}{r}1.30- \\
1.46\end{array}$ & $\begin{array}{r}2.35- \\
6.67\end{array}$ & $\begin{array}{r}0.38- \\
1.82\end{array}$ \\
\hline 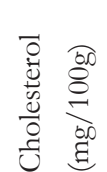 & $\begin{array}{c}8.89- \\
10.24\end{array}$ & $14-23$ & $\begin{array}{c}16.9- \\
18.09\end{array}$ & $5-8.8$ & $\begin{array}{l}31.3- \\
37.10\end{array}$ & 5-8 \\
\hline
\end{tabular}

sorbtion from the intestines. Moreover, the presence of medium-chain FA (caproic, caprylic, capric) of the goat milk helps in reduction cholesterol in human by limiting cholesterol stores and increasing mobilization. Also, allergic activity is less than of cow milk. The small size of the fat globules makes it easier to form cream. Although buffalo milk has high fat, its cholesterol level is low (20). However, camel milk is rich in polyunsaturated FAs with a high cholesterol content (13).

Donkey and mare milks have low fat and cholesterol con- 
tent (Table 2.6), while they are rich in unsaturated FAs such as omega 3 and omega 6 (9.45-9.50, 11.57-13.09 g/100 g FA in donkey milk; 8.66-11.97, 7.06- $11.77 \mathrm{~g} / 100 \mathrm{ml}$ in mare milk respectively) (24).

\subsubsection{MILK SUGAR: LACTOSE}

The only source of lactose, which is composed of glucose and galactose, is animal milk. Lactose is the only carbohydrate found in animal milk and not found in herbal milk. Lactose is composed of one-third of dry milk matter and its ratio in drinkable animal-derived milk is about to $5 \%$. This rate is slightly higher in human milk and mare milk. Aromatized milk contains maltose and sucrose beside lactose; soy milk also contains other carbohydrates such as sucrose (6) (Table 2.7).

While the blood passes through the breast tissue, about $20 \%$ of the blood sugar is converted to lactose. In market, there is lactose-free milk that is destroyed lactose by lactase enzyme and lactose converts to glucose and galactose. Lactose

Table 2.7. Total carbohydrates and lactose contents of different milk types (for $100 \mathrm{~g}$ milk.)

\begin{tabular}{lcc}
\hline Milk typeS & Total carbohydrates (g) & Lactose (g) \\
\hline Cow, pasteurized & $4.6 \mathrm{a}$ & $4.6 \mathrm{a}$ \\
Goat, pasteurized & $4.4 \mathrm{a}$ & $4.4 \mathrm{a}$ \\
Human (Mature) & $7.2 \mathrm{a}$ & $7.2 \mathrm{a}$ \\
Sheep (raw) & $5.1 \mathrm{a}$ & $5.1 \mathrm{a}$ \\
Mare & $6.83 \mathrm{~b}$ & $6.83 \mathrm{~b}$ \\
Camel & $4.9 \mathrm{c}$ & $4.9 \mathrm{c}$ \\
Donkey & $6.33 \mathrm{~d}$ & $6.33 \mathrm{~d}$ \\
Aromatized cow & $9.6 \mathrm{a}$ & $4.9 \mathrm{a}$ \\
(strawberry, banana) & & \\
Aromatized cow & $11.7 \mathrm{a}$ & $5.5 \mathrm{a}$ \\
(chocolate) & & $0.5 \mathrm{a}$ \\
Soy (sweetened) & & \\
\hline
\end{tabular}

a: 6, b: $17, \mathrm{c:} 12, \mathrm{~b}: 4$

is not an energy source carbohydrate.. However, galactose, that is formed by the destruction of the lactose in digestive system, is especially the source of the brain tissue and glycolipids. Brain development is closely related to the amount of consumed lactose (13).

Mare milk has high quantity of the water and lactose and it is very sweety. It is used for production of the kumiss (13). The fact that mare milk is easily digestable and sufficient for essential nutrients, increase its importance especially in childhood nutrition. In the most recent surveys in the world, more than 30 million mare milk consumers are present, and this number is growing. Although, fat, protein and inorganic salt amounts of the mare milk is lower than the cow milk, lactose content is higher than of the cow milk and close to human milk composition (25). Mare and donkey milks have the highest lactose content in comparison to all milk types $(4,17)$.

\subsection{4. \\ MILK VITAMINS}

Milk includes almost all vitamins that humans needs (Table 2.8). The amounts of vitamins $A, D, E$ and $K$, which are known as fat-soluble vitamins, are related to milk fat and as the milk fat decrease, the fat soluble vitamins also decrease. Milk, also contains water-soluble vitamins. Carotenoids and riboflavins are the ones that give color to the milk fat, and they give a yellowish and fluorescent colors, respectively. Goat milk is whiter than the others because of the low carotene content (26).

As shown in Table 2.8, while the casein milk has more abundant in vitamin B and vitamin A, mare and donkey milks are poorer in those.

Table 2.8. Vitamin content of different animal milk types /200 $\mathrm{ml}$

\begin{tabular}{|c|c|c|c|c|c|c|c|c|}
\hline Vitamins & త & 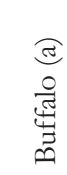 & $\begin{array}{l}\text { త্ } \\
\text { हि } \\
\frac{d}{\infty}\end{array}$ & \begin{tabular}{l} 
Ð0 \\
\multirow{2}{0}{} \\
0 \\
0
\end{tabular} & 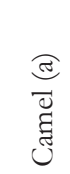 & 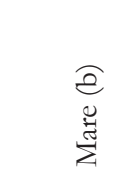 & $\begin{array}{l}\hat{e} \\
\text { 总 } \\
\stackrel{0}{0}\end{array}$ & 点 \\
\hline $\begin{array}{l}\text { Thiamine } \\
(\mathrm{B} 1)(\mu \mathrm{g})\end{array}$ & 80 & 100 & 160 & 80 & 80 & $40-80$ & $42-120$ & 1400 \\
\hline $\begin{array}{l}\text { Riboflavin } \\
(\mu g)\end{array}$ & 324 & 200 & 712 & 260 & 120 & $20-74$ & 60-194 & 1600 \\
\hline Niacin $(\mu g)$ & 168 & 520 & 832 & 620 & 800 & $140-280$ & $114-180$ & 18000 \\
\hline $\begin{array}{l}\text { Vitamin B6 } \\
(\mu g)\end{array}$ & 120 & 760 & 160 & 120 & 100 & 60 & & 2000 \\
\hline $\begin{array}{l}\text { Vitamin B12 } \\
(\mu g)\end{array}$ & 0.7 & 0.6 & 1.4 & 0.2 & 4.0 & 0.6 & & 2.5 \\
\hline Folate $(\mu \mathrm{g})$ & 10 & 20 & 12 & 20 & 0.2 & 0.26 & & 400 \\
\hline $\begin{array}{l}\text { Pantotenate } \\
(\mu g)\end{array}$ & 628 & 300 & 816 & 820 & 180 & $550-600$ & & 5000 \\
\hline Biotin $(\mu g)$ & 4.0 & 5.2 & 10.0 & 6 & & & & 30 \\
\hline $\begin{array}{l}\text { Vitamin C } \\
(\mathrm{mg})\end{array}$ & 1.8 & 5.0 & 1.9 & 2.6 & & $4.8 \mathrm{a}$ & 4 & 60 \\
\hline $\begin{array}{l}\text { Vitamin A } \\
(\mu g)\end{array}$ & 104 & 140 & 168 & 88 & 30 & $68 \mathrm{a}$ & 3.4 & 1000 \\
\hline $\begin{array}{l}\text { Vitamin D } \\
(\mu g)\end{array}$ & 0.36 & 0.00 & 0.06 & 0.22 & $\begin{array}{r}0.6- \\
3.2\end{array}$ & $0.60 \mathrm{a}$ & $4.6 \mathrm{c}$ & 5 \\
\hline $\begin{array}{l}\text { Vitamin E } \\
(\mathrm{mg})\end{array}$ & 0.18 & 0.20 & 0.22 & 0.06 & 0.01 & $\begin{array}{r}0.05- \\
0.23\end{array}$ & 0.10 & 15 \\
\hline
\end{tabular}

a: 28, b: 14, c: 27, d: 29

RDA: Recommendend Dietary Allowance

The fact that camel milk contains 3-5 times more vitamin C than cow milk makes it more acidic and makes it unfavorable environment for the bacteria so that camel milk can be kept for a long time (21). Goat milk is not rich in vitamin B12 and iron, it is recommended to be used for feeding of infants and 
for people who have digestive problems. Although the total vitamin content of milk changes according to the feed content, water-soluble vitamin composition is effected more (13).

Since the vitamins are heat sensitive, the UHT process reduce vitamin $\mathrm{C}$, folate and vitamin B6 levels considerably, while it decrease thiamine, B12 and pantothenate contents slightly (27). In table 2.9 shows that as the fat content of milk reduces, some of its vitamins decrease.

Table 2.9. Vitamin contents of different types of the pasteurized cow milk /200 $\mathrm{ml}$ (30)

\begin{tabular}{|c|c|c|c|c|}
\hline Vitamins & Whole & Semi-skimmed & Skimmed & $\begin{array}{r}\text { RDA for } \\
\text { adults }\end{array}$ \\
\hline Thiamine $(\mu \mathrm{g})$ & 80 & 80 & 60 & 1400 \\
\hline Riboflavin $(\mu \mathrm{g})$ & 480 & 500 & 460 & 1600 \\
\hline Niacin $(\mu \mathrm{g})$ & 3200 & 1400 & 1600 & 18000 \\
\hline Vitamin B6 $(\mu \mathrm{g})$ & 120 & 120 & 120 & 2000 \\
\hline Vitamin B12 ( $\mu \mathrm{g})$ & 0.8 & 0.8 & 0.9 & 2.5 \\
\hline Folate $(\mu \mathrm{g})$ & 6 & 6 & 6 & 400 \\
\hline Pantotenate ( $\mu \mathrm{g})$ & 700 & 700 & 800 & 5000 \\
\hline Biotin $(\mu \mathrm{g})$ & 5 & 6 & 7 & 30 \\
\hline Vitamin C (mg) & 4 & 4 & 3 & 60 \\
\hline Vitamin A $(\mu \mathrm{g})$ & 62 & 40 & 2 & 1000 \\
\hline Vitamin D $(\mu \mathrm{g})$ & $\dot{\mathrm{I} z}$ & $\dot{\mathrm{I}} z$ & $\dot{\mathrm{I}} \mathrm{z}$ & 5 \\
\hline Vitamin E (mg) & 0.18 & 0.20 & 0.22 & 15 \\
\hline
\end{tabular}

\subsubsection{MILK MINERALS}

Milk is a rich source of calcium, phosphorus, sodium, potassium, chloride, iodine and magnesium. Calcium and phosphorus are the main minerals in milk and they are responsible from the bone growth and development. The bioavailability of calcium is directly proportional to the casein concentration. As shown in table 2.10, especially sheep milk has higher calcium contents and most of the other mineral levels, donkey milk is the poorest milk in terms of calcium and the other minerals. While iron, zinc, and copper in ruminant milks are mainly bound to casein fraction, these minerals are bound to water-soluble proteins in human milk. As well as the amount of iron in milk is generally low, goat milk has the lowest and camel milk has the highest one. Although the iron amount of goat milk is low, its bioavailability is higher than of the cow milk because it contains more nucleotides that are involved in
Table 2.10. Mineral content of different animal milk types

\begin{tabular}{|c|c|c|c|c|c|c|c|c|}
\hline Minerals & 苞 & 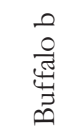 & $\begin{array}{l}u \\
\ddot{u} \\
\text { un }\end{array}$ & 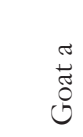 & $\begin{array}{l}\vec{\Xi} \\
\vec{\Xi} \\
\text { ज्ञ }\end{array}$ & $\begin{array}{l}0 \\
\stackrel{0}{*}\end{array}$ & 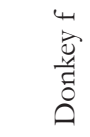 & 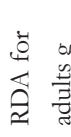 \\
\hline \multicolumn{9}{|l|}{$\mathrm{mg} / 100 \mathrm{mg}$} \\
\hline Sodium & 58 & 35 & $44-58$ & 41 & 59 & 19.8 & 21.83 & 1500 \\
\hline Potassium & 152 & 92 & $\begin{array}{r}136- \\
140\end{array}$ & 181 & 144 & 66.5 & 49.72 & 4700 \\
\hline Calcium & 122 & 112 & $\begin{array}{r}195- \\
200\end{array}$ & 134 & 114 & 132.7 & 67.7 & 1200 \\
\hline $\begin{array}{l}\text { Magnesi- } \\
\text { um }\end{array}$ & 12 & 8 & $18-21$ & 16 & $\begin{array}{r}10.5- \\
12.3\end{array}$ & 10.2 & 3.73 & 420 \\
\hline $\begin{array}{l}\text { Phospho- } \\
\text { rus }\end{array}$ & 119 & 99 & $\begin{array}{l}124- \\
158\end{array}$ & 121 & 87.4 & 88.4 & 48.7 & 700 \\
\hline \multicolumn{9}{|l|}{$\mu \mathrm{g} / 100 \mathrm{~g}$} \\
\hline Zinc & 530 & 410 & $\begin{array}{r}520- \\
747\end{array}$ & 56 & 590 & 270 & & 8000 \\
\hline Iron & 80 & 161 & $72-122$ & 7 & 230 & 37 & & 900 \\
\hline Copper & 60 & 35 & $40-68$ & 355 & 140 & 64 & & 8000 \\
\hline Manganese & 20 & 27 & & 273.2 & 80 & & & 2300 \\
\hline İodine & 2.1 & & & 2.2 & & & & 55 \\
\hline Selenium & 0.96 & & & 1.33 & & & & 150 \\
\hline
\end{tabular}

Vahčić, Hruškar (31) reported that as the fat content decreases, the amount of calcium also decreases but- the phosphorus ratio increases in the cow milk (Table 2.11).

Table 2.11. Mineral content of cow milk in different fat ratio (31)

\begin{tabular}{lllllllll}
\hline & $\mathrm{Ca}$ & $\mathrm{P}$ & $\mathrm{Mg}$ & $\mathrm{Fe}$ & $\mathrm{Cu}$ & $\mathrm{Zn}$ & $\mathrm{K}$ & $\mathrm{Na}$ \\
\hline $3.6 \%$ of fat & 93 & 97 & 13 & 0.06 & 0.024 & 0.37 & 158 & 49 \\
$2.8 \%$ of fat & 90 & 93 & 11 & 0.07 & 0.019 & 0.32 & 156 & 49 \\
$1.6 \%$ of fat & 85 & 96 & 12 & 0.1 & 0.019 & 0.33 & 157 & 46 \\
$0.9 \%$ of fat & 89 & 105 & 11 & 0.053 & 0.017 & 0.35 & 158 & 46
\end{tabular}

\section{PLANT-BASED MİLK}

Although cow milk is the most consumed milk in the wor$\mathrm{ld}$, it is also the most allergic food for babies and children. Allergic properties of animal-based milk and dairy products have caused to production of alternative milk products such as plant-based milk. Another factor that promotes plant-baseds 
milk production is lactose intolerance which is present in 15$75 \%$ of humans and resulting from the absence of the lactase enzyme, which breaks down lactose. The lack of lactose in herbal milk makes the plant-based milk an alternative for people with lactose intolerance (35). Also the gaining popularity of the vegan diet in the world and cholesterol content of the animal milk and, has also been a reason for the production of the alternative milk. One of the reasons for the choice of plant-based milk since it does not contain cholesterol as seen in table 3.1 and the fat ratios of some of them (almond milk, rice milk) are low. However, the fact that only soy milk is rich in protein among plant-based milk has a disadvantage in the consumption of them. (Table 3.1).

Almond milk is rich in monounsaturated FAs and reduces LDL concentration, and helps to weight control because of its low calories. Also, it is rich in protein, fiber, manganese, calcium and vitamin E. Moreover, it has more vitamin A, D and $\mathrm{E}$ than the other herbal milk and cow milk. It is obtained by wetting and grinding the almonds with large amounts of water. Its color is darker beige than of cow milk. While calcium content is more than cow milk; the protein content is lower.
That it can be prepared at home, increases the usage in infants and children. The risk of allergy against almond is the primary disadvantage. (36).

Since $35 \%$ of soybean seed is composed of protein, soy milk is very important protein source, especially for vegetarians, but it also has allergen properties. Another important advantage of soybean seed is that it contains isoflavonoids which have antitumor, anti-stiffness and osteoporosis-reducing properties (37). However, soybean is not preferred as often as it is shown among genetic modified organisms. However, investors started to produce organic soybean milk in order to gain the former popularity of soy milk and have succeeded in increasing their place in the markets every day. Soy milk has high protein, fat and fiber contents. It takes an important place in vegan nutrition. Usually, the soy milk, that we can see in the boxes on the shelves, can be cooked. If the nutritional values are examined, a glass of soy milk contains about 9 grams of protein, 5 grams of carbohydrates and 4.5 grams of fat. It contains a small amount of vitamin $\mathrm{B}$, it is also not a good source of vitamin B12. It is not as rich as cow milk in terms of vitamin $\mathrm{A}$ and $\mathrm{D}$. Also, calcium content of soy milk varies.

Table 3.1. Comparison of the contents of some plant-based milks with cow milk/100 g. Adapted from Vanga and Raghavan (36).

\begin{tabular}{|c|c|c|c|c|c|c|}
\hline & Almond milk & Soy milk & Rice milk & Coconut milk & Cow milk & $\mathrm{RDA}$ \\
\hline Carbohydrates (g) & $1.32 \pm 0.90$ & $5 \pm 1.83$ & $25.28 \pm 1.7$ & $1.19 \pm 0.56$ & 4.65 & 130 \\
\hline Fat (g) & $2.71 \pm 0.48$ & $4.35 \pm 1.14$ & $2.33 \pm 0.31$ & $4.38 \pm 0.48$ & $3.66 \pm$ & 35 \\
\hline Saturated FA & 0 & $0.64 \pm 0.38$ & $0.16 \pm 0.22$ & $4.13 \pm 0.63$ & 2.28 & \\
\hline MUFA & $1.67 \pm 0.29$ & $0.84 \pm 0.23$ & $1.16 \pm 0.59$ & - & 1.06 & \\
\hline PUFA & $0.67 \pm 0.28$ & $2.4 \pm 0.65$ & $0.83 \pm 0.75$ & - & 0.14 & \\
\hline Cholesterol & 0 & 0 & 0 & 0 & 14 & \\
\hline Protein (g) & $1.67 \pm 1.63$ & $8.71 \pm 1.6$ & $0.85 \pm 0.75$ & 0 & 3.28 & 55 \\
\hline \multicolumn{7}{|l|}{ Minerals (mg) } \\
\hline Calcium & $325.29 \pm 193.55$ & $205.86 \pm 173.54$ & $245.5 \pm 149.67$ & $244.75 \pm 206.84$ & 119 & 1100 \\
\hline Iron & $0.18 \pm 0.13$ & $0.84 \pm 0.78$ & $0.13 \pm 0.18$ & $0.1 \pm 0.06$ & 0.12 & 6.5 \\
\hline Magnesium & $21 \pm 9.9$ & $49 \pm 20.4$ & 35 & 35 & 32 & 350 \\
\hline Phosphorus & $48 \pm 62.35$ & $108 \pm 40.25$ & $63 \pm 38.19$ & - & 230 & 600 \\
\hline Potassium & $65 \pm 58.84$ & $364.29 \pm 66.5$ & 50 & $46.67 \pm 11.55$ & 373 & 4700 \\
\hline Sodium & $146.42 \pm 36.25$ & $65 \pm 43.49$ & $72 \pm 22.53$ & $63.75 \pm 64.21$ & 121 & 1500 \\
\hline Zinc & $0.56 \pm 0.4$ & $0.75 \pm 0.19$ & $0.75 \pm 0.27$ & $0.66 \pm 0.4$ & 0.94 & 9.4 \\
\hline \multicolumn{7}{|l|}{ Vitamins } \\
\hline Vit C (mg) & 0 & 0 & 0 & 0 & 1.5 & 75 \\
\hline Tiamine (mg) & & $0.08 \pm 0.02$ & & - & 0.04 & 1 \\
\hline Riboflavin (mg) & $0.19 \pm 0.15$ & $0.24 \pm 0.12$ & $0.30 \pm 0.04$ & - & 0.16 & 1.1 \\
\hline Niacin (mg) & - & $0.28 \pm 0.23$ & - & - & 0.08 & 11 \\
\hline Vit B6 (mg) & - & $0.096 \pm 0.024$ & - & - & 0.04 & 1.2 \\
\hline Folate $(\mu \mathrm{g})$ & 19.2 & $33.6 \pm 20.37$ & - & $19.2 \pm$ & 5 & 320 \\
\hline Vit 12 ( $\mu \mathrm{g})$ & 1 & $0.68 \pm 0.38$ & 1 & $0.75 \pm 0.29$ & 0.36 & 2 \\
\hline Vit A ( $\mu \mathrm{g})$ & $77.14 \pm 45.35$ & $32.57 \pm 28.32$ & $67.5 \pm 61.85$ & 60 & 33 & 600 \\
\hline Vit E (mg) & $3.84 \pm 2.15$ & 4 & 3 & - & 0.18 & 12 \\
\hline Vit D ( $\mu g)$ & $2.32 \pm 0.88$ & $1.86 \pm 0.97$ & $2.09 \pm 1.48$ & $2.92 \pm 0.48$ & 0.36 & 10 \\
\hline Enerji (kcal) & $36.43 \pm 6.90$ & $95 \pm 15.6$ & $133 \pm 13.04$ & $48.75 \pm 7.5$ & 64 & \\
\hline
\end{tabular}

MUFA: Mono-unsaturated fatty acid, PUFA: Poly-unsaturated fatty acid 
Some are rich in calcium, some are not. To cope with these deficiencies, the producers produced the varieties of soy milk containing calcium, E, B12 and vitamin D (38).

As the rice milk obtained by soaking the brown rice in water, it is a rich source of carbohydrates, the sugar content is higher than cow milk. The absence of an allergen effect contrary to soy and almond is the primary advantage of it (39). As homemade rice milk has not enough $\mathrm{Ca}$ and vitamin B12, consumption for a long time can cause nutritional deficiency. Rice milk is more watery consistence in comparison to other herbal sources. It is similar to cow milk. Protein content is low like almond milk but it is sweeter. Although the protein ratio is quite low, they have complex carbohydrates and have a very rich fiber content. Rice milk, which contains calcium, natural phosphorus, vitamin B, D and E, both can be drunk directly and it also constitutes the main input of various products (37).

\section{ANTIOXIDANT PROPERTIES OF THE MILK}

Excessive amounts of free oxygen radicals that occur during metabolic process and lack of optimal amounts of antioxidants cause oxidative damage. The synthesis and accumulation of reactive oxygen species at the cellular level are controlled by antioxidants (40). Total antioxidant activity in different milk types is given in Table 4.1. Casein, milk proteins (LA, LG, xanthine oxidase, LF etc.), peptides and amino acids that are formed by protein breakdown, antioxidant enzymes such as catalase (CAT), glutathione peroxidase (GPX), lactoperoxidase (LP), superoxide dismutase (SOD), vitamins such as vitamin $\mathrm{A}$, provitamins, carotenoids, vitamin $\mathrm{C}$ and $\mathrm{E}$ inducethe antioxidant activity in animal milk (Table 4.2, 4.3). Antioxidant activity in plant-based milk consists of phenolic compounds, flavonoids, vitamin A, E and C (41).

The components resulting from enzymatic hydrolysis or fermentation of proteins in animal milk may play an antihypertensive, antimicrobial, opioid, antioxidant, immunomodulatory, or mineral-binding role. These protein components are bioactive peptides formed by inactive protein precursors during the digestion of milk in the gastrointestinal tract. Due to these properties, milk proteins are used in support nutrients and pharmaceutical applications. Bioactive proteins and peptides originating from milk are essential in controlling microbial infections and providing protection against non-immune diseases. Generally, the total antibacterial effect of milk is considered to be higher than the individual effects of Igs and non-Ig defense proteins such as LF, LP, lysozyme, and peptides. The estimated reason of this situation may be due to the synergistic effect of naturally occurring proteins and peptides and peptides that produced from inactive protein precursors (42).

Donkey milk is different from cow, sheep and goat milks due to its high lysozyme and LF content, alsohigh antimicrobial activity (4). As $\alpha$-LA in camel and human milk have high level of essential amino acids, they have more antioxidant activities and antitumor effects (21). In the study performed by Amati et al.(43) reported that regular daily goat milk consumption suppressed acute inflammation, was increased IL- 8 and IL- 6 that are released from acute phase proteins, and suppressed IL-1B and TNF- $\alpha$ production.
Table 4.1. Total antioxidant activity of the different milk types

\begin{tabular}{llr}
\hline Milk types & Total antioxidant activity & Reference \\
\hline $0.1 \%$ of fat, pasteurized, cow & $1246 \mu \mathrm{mol} / \mathrm{L}$ & $(49)$ \\
$0.1 \%$ of fat, raw, cow & $1249 \mu \mathrm{mol} / \mathrm{L}$ \\
$1.5 \%$ of fat, pasteurized, cow & $1852 \mu \mathrm{mol} / \mathrm{L}$
\end{tabular}

$3 \%$ of fat, pasteurized, cow $2241 \mu \mathrm{mol} / \mathrm{L}$

Sheep (Berrichon du cher)

Colostrum 0. min

$4.74 \mu \mathrm{mol} / \mathrm{g}$ prt

Colostrum $12 \mathrm{~h}$

$7.73 \mu \mathrm{mol} / \mathrm{g}$ prt

Colostrum 48 h

$10.56 \mu \mathrm{mol} / \mathrm{g}$ prt

Mature 5. d

$9.73 \mu \mathrm{mol} / \mathrm{g}$ prt

Sheep (Uhruska)

Colostrum 0 min

$4.78 \mu \mathrm{mol} / \mathrm{g}$ prt

Colostrum $12 \mathrm{~h}$

$6.63 \mu \mathrm{mol} / \mathrm{g}$ prt

Colostrum $48 \mathrm{~h}$

$7.72 \mu \mathrm{mol} / \mathrm{g}$ prt

Mature 5. d

$6.69 \mu \mathrm{mol} / \mathrm{g}$ prt

Cow (Holstein-Fresian)

Colostrum 0 min

$3.92 \mu \mathrm{mol} / \mathrm{g}$ prt

Colostrum $24 \mathrm{~h}$

$6.81 \mu \mathrm{mol} / \mathrm{g}$ prt

Colostrum $48 \mathrm{~h}$

$9.37 \mu \mathrm{mol} / \mathrm{g}$ prt

Mature 6th d

$13.41 \mu \mathrm{mol} / \mathrm{g}$ prt

Goat (Prisca)

$66.7 \mathrm{mmol} / \mathrm{L} \alpha$ tocopherol

Goat (Saanen)

eşdeğeri

Donkey

$35.8 \mathrm{mmol} / \mathrm{L} \alpha$ tocopherol eşdeğeri

$31.2 \mathrm{mmol} / \mathrm{L} \alpha$ tocopherol eşdeğeri

Camel

$3.6 \pm 0.14 \mathrm{mmol} / \mathrm{L}$

Buffalo

$0.8 \mathrm{mmol}$ Trolox eq/L

Soy (yellow) milk

$0.35 \pm 0.04 \mu \mathrm{mol}$ Trolox

Soy (black) milk

$\mathrm{eq} / \mathrm{g}$

Coconut milk

$0.99 \pm 0.03 \mu \mathrm{mol}$ Trolox

$\mathrm{eq} / \mathrm{g}$

$610.19 \pm 2.54$ (mg Trolox

eq/100g)

Alyaqoubi et al. (44) indicated that the total antioxidative activity of coconut milk was higher than of cow and goat milk. Besides, it was notified that antioxidant properties of soy milk 
Table 4.2. Some antioxidant enzyme activities of the different milk types

\begin{tabular}{|c|c|c|c|c|}
\hline & SOD & CAT & GPX & $\mathrm{LF}$ \\
\hline Human colostrum & $6.2 \mathrm{nmol} / \mathrm{min} / \mathrm{ml}$ (a) & $26 \mathrm{nmol} / \mathrm{min} / \mathrm{ml}$ (a) & & $16.2 \mathrm{~g} / \mathrm{L}(\mathrm{a})$ \\
\hline Transition milk & $2.8 \mathrm{nmol} / \mathrm{min} / \mathrm{ml}$ (a) & $8.7 \mathrm{nmol} / \mathrm{min} / \mathrm{ml}$ (a) & & $12.3 \mathrm{~g} / \mathrm{L}(\mathrm{a})$ \\
\hline Cow milk & 0-92 U/ml Holstein & $1-95 \mathrm{U} / \mathrm{ml}(\mathrm{d})$ & $12-32 \mathrm{U} / \mathrm{ml}(\mathrm{d})$ & $20-200 \mu \mathrm{g} / \mathrm{ml}(\mathrm{h})$ \\
\hline Sheep milk & $382.48 \pm 6.98$ (c) & $207.93 \pm 25.92$ (c) & $51.8 \mathrm{U} / \mathrm{ml}(\mathrm{g})$ & \\
\hline
\end{tabular}

a: 54, b: 55, c: 56, d: 57, e: 58, f: 59, g: 49, h: 16

are originated from the flavonoids (41), and antioxidant properties of almond milk and coconut milk are caused by high vitamin E content (36).

While, Smet et al (45) notified that antioxidant capacity of low-fat pasteurized milk is slightly lower since it contains less unsaturated FA than whole milk, Zulueta et al (46) showed that antioxidant activity of pasteurized milk is higher than the UHT milk. Vitamin A and vitamin E levels in UHT, raw and pasteurized milk samples indicated in Table 4.3 (47).

Table 4.3. Contents of the $\beta$-karoten, Retinol ve vitamin $\mathrm{E}$ in different cow milk types. It is modified from Chotyakul et al (47)

\begin{tabular}{|c|c|c|c|}
\hline Milk types & $\begin{array}{r}\beta \text {-carotene } \\
(\mathrm{mg} / \mathrm{L})\end{array}$ & $\begin{array}{l}\text { Retinol } \\
(\mathrm{mg} / \mathrm{L})\end{array}$ & $\begin{array}{r}\alpha \text {-Tocopherol } \\
(\mathrm{mg} / \mathrm{L})\end{array}$ \\
\hline Raw & $0.16-0.18$ & 0.73-0.89 & $0.59-0.73$ \\
\hline Organic, raw & $0.29-1.02$ & $1.02-1.08$ & $1.11-1.12$ \\
\hline $\begin{array}{l}\text { Pasteurized, } \\
\text { whole }\end{array}$ & 0.17 & 1.07 & 0.07 \\
\hline $\begin{array}{l}\text { Pasteurized, } \\
\text { semi-skimmed }\end{array}$ & 0.1 & 5.54 & 0.82 \\
\hline $\begin{array}{l}\text { Pasteurized, } \\
\text { skimmed }\end{array}$ & 0.04 & 4.14 & 0.4 \\
\hline $\begin{array}{l}\text { Pasteurized, orga- } \\
\text { nic, skimmed }\end{array}$ & $0.22-0.27$ & $0.88-0.93$ & $0.82-0.93$ \\
\hline UHT, whole & $0.06-0.08$ & $0.75-0.82$ & $0.6-1.41$ \\
\hline $\begin{array}{l}\text { UHT semi-skim- } \\
\text { med }\end{array}$ & $0.03-0.62$ & $0.23-0.29$ & $0.3-0.43$ \\
\hline UHT skimmed & $0.04-0.06$ & $0.06-0.09$ & $0.07-0.09$ \\
\hline
\end{tabular}

\section{RESULT}

Milk is a beverage which contain the basic nutrients of a balanced diet. In 2018, more than 10 million tons cow milk are collected in our country in according to the Turkey Statistics Institution data and 1 million 650 thousand tons of which is considered as drinking milk. While world annually milk consumption per person in 2015 is $111.3 \mathrm{~kg}$ according to the International Dairy Council, this figure was $34 \mathrm{~kg}$ in Turkey in 2016 according to the Turkey Statistics Institution data. More- over, as the consumption of milk and milk products is $300 \mathrm{~kg} /$ person in European countries such as Australia, Norway, France and Germany, this figure is $231 \mathrm{~kg} /$ person in our country according to 2016 data. Due to our consumption is low compared to the world average, it is necessary to raise the awareness of the people about the benefits of milk and alternative milk resources and increase the milk consumption.

\section{REFERENCES}

1. Salimei E, Fantuz F, Coppola R, Chiofalo B, Polidori P, Varisco G. Composition and characteristics of ass's milk. Anim Res. 2004; 53(1): 67-78.

2. Hosoi S, Honma K, Daimatsu T, Kiyokawa M, Aikawa $\mathrm{T}$, Watanabe $\mathrm{S}$. Lower energy content of human milk than calculated using conversion factors. Pediatrics Int. 2005; 47(1): 7-9.

3. Solaroli G, Pagliarini E, Peri C. Composition and nutritional quality of mare's milk. Italian J Food Sci. 1993; 1: 3-10. 4. Vincenzetti S, Polidori P, Mariani P, Cammertoni N, Fantuz F, Vita A. Donkey's milk protein fractions characterization. Food Chemistry. 2008; 106(2): 640-9.

5. Rudd LB. Milk Fat: Composition, Nutritional Value and Health Implications. New York: Nova Science Publishers, Inc; 2013.

6. McCance and Widdowson's the composition of foods integrated dataset [16.02.2019]. Available from: https: // www.gov.uk/government/publications/composition-of-foods-integrated-dataset-cofid.

7. Eskin NAM, Shahidi F. Biochemistry of Foods. Burlington: Academic Press; 2012.

8. Park YW. Bioactive components in milk and dairy products: John Wiley \& Sons; 2009.

9. El-Agamy E. The challenge of cow milk protein allergy. Small Rum Res. 2007; 68(1-2): 64-72.

10. Sørensen ES, Rasmussen LK, Møller L, Petersen TE. The Localization and multimeric nature of component PP3 in bovine Milk: Purification and characterization of PP3 from caprine and ovine Milks. J Dairy Sci, 1997; 80(12): 3176-81. doi: https: //doi.org/10.3168/jds.S0022-0302(97)76289-1.

11. Guo H, Pang K, Zhang X, Zhao L, Chen S, Dong M, et al. Composition, physiochemical properties, nitrogen fraction distribution, and amino acid profile of donkey milk. J Dairy Sci. 2007; 90(4): 1635-43. 
12. Brumini D, Criscione A, Bordonaro S, Vegarud GE, Marletta D. Whey proteins and their antimicrobial properties in donkey milk: a brief review. Dairy Sci Technol. 2016; 96(1): $1-14$.

13. Markiewicz-Kęszycka M, Czyżak-Runowska G, Lipińska P, Wójtowski J. Fatty acid profile of milk-a review. Bull Vet Inst Pulawy. 2013; 57(2): 135-9.

14. Claeys W, Verraes C, Cardoen S, De Block J, Huyghebaert A, Raes $\mathrm{K}$, et al. Consumption of raw or heated milk from different species: An evaluation of the nutritional and potential health benefits. Food Control. 2014; 42: 188-201.

15. Raynal-Ljutovac K, Lagriffoul G, Paccard P, Guillet I, Chilliard Y. Composition of goat and sheep milk products: An update. Small Rum Res. 2008; 79(1): 57-72.

16. Park Y, Juárez M, Ramos M, Haenlein G. Physico-chemical characteristics of goat and sheep milk. Small Rum Res. 2007; 68(1-2): 88-113.

17. Naert L, Vande Vyvere B, Verhoeven G, Duchateau L, De Smet S, Coopman F. Assessing heterogeneity of the composition of mare's milk in Flanders. Vlaams Diergeneeskd Tijdschr. 2013; 82(1): 23-30.

18. Khaskheli M, Arain M, Chaudhry S, Soomro A, Qureshi T. Physico-chemical quality of camel milk. J Agric Soc Sci. 2005; 2: 164-6.

19. Shamsia S. Nutritional and therapeutic properties of camel and human milks. Int J Genet Mol Biol. 2009; 1(4): $052-$ 8 .

20. Lara-Villoslada F, Olivares M, Xaus J. The balance between caseins and whey proteins in cow's milk determines its allergenicity. J Dairy Sci. 2005; 88(5): 1654-60.

21. El-Hatmi H, Jrad Z, Salhi I, Aguibi A, Nadri A, Khorchani T. Comparison of composition and whey protein fractions of human, camel, donkey, goat and cow milk. Mljekarstvo/Dairy. 2015; 65(3).

22. Jensen RG, Ferris AM, Lammi-Keefe CJ. The Composition of Milk Fat. J Dairy Sci. 1991; 74(9): 3228-43.

23. Gebhardt SE. Nutritive value of foods: DIANE Publishing; 1994. page are missing

24. Salimei E, Fantuz F. Equid milk for human consumption. Int Dairy J. 2012; 24(2): 130-42.

25. Tegin RAA, Z G. All aspects of koumiss the natural fermented product. MANAS J Eng. 2014; 2(1): 23-34.

26. Starbard A, Winscher K, Noll E. The Dairy Goat Handbook : For Backyard, Homestead, and Small Farm. Minneapolis, Minnesota: Voyageur Press; 2015.

27. Gordon I. Minerals and Vitamins in Milk and Dairy Products. In: Kanekanian A, editor. Milk and Dairy Products as Functional Foods. p. 289-313, John Wiley \& Sons, Ltd; 2014.

28. Barłowska J, Szwajkowska M, Litwińczuk Z, Król J. Nutritional value and technological suitability of milk from various animal species used for dairy production. Compr Rev Food Sci Food Saf. 2011; 10(6): 291-302.

29. Human vitamin and mineral requirements : FAO/ WHO expert consultation on human vitamin and mineral requirements Food and Nutrition Division FAO Rome2001 [16 Şubat 2019]. Available from: http://www.fao.org/3/ay2809e.pdf.

30. Scott KJ, Bishop DR. Nutrient content of milk and milk products: vitamins of the $\mathrm{B}$ complex and vitamin $\mathrm{C}$ in retail market milk and milk products. Int J Dairy Technol. 1986; 39(1): 32-5. doi: 10.1111/j.1471-0307.1986.tb02356.x.

31. Vahčić N, Hruškar M, Marković K, Banović M, Barić IC. Essential minerals in milk and their daily intake through milk consumption. Mljekarstvo/Dairy. 2010; 60(2).77-85.

32. Patino E, Pochon D, Faisal E, Cedres J, Mendez F, Stefani C, et al. Influence of breed, year season and lactation stage on the buffalo milk mineral content. Italian J Anim Sci. 2007; 6(sup2): 1046-9.

33. Mehaia MA, Hablas MA, Abdel-Rahman KM, El-Mougy SA. Milk composition of Majaheim, Wadah and Hamra camels in Saudi Arabia. Food Chemistry. 1995; 52(2): 115-22.

34. Schryver H, Oftedal OT, Williams J, Soderholm L, Hintz H. Lactation in the horse: the mineral composition of mare milk. J Nutr. 1986; 116(11): 2142-7.

35. Bahna SL. Cow's milk allergy versus cow milk intolerance. Ann Allergy Asthma Immunol. 2002; 89(6): 56-60.

36. Vanga SK, Raghavan V. How well do plant based alternatives fare nutritionally compared to cow's milk? J Food Sci Technol. 2018; 55(1): 10-20. doi: 10.1007/s13197-0172915-y.

37. Omoni AO, Aluko RE. The anti-carcinogenic and anti-atherogenic effects of lycopene: a review. Trends Food Sci Technol. 2005; 16(8): 344-50.

38. Karabudak E. Vejetaryen beslenmesi. Sağlık Bakanlığ1 Yayın1. 2012.

39. Lomer M, Parkes G, Sanderson J. lactose intolerance in clinical practice-myths and realities. Aliment Pharm Ther. 2008; 27(2): 93-103.

41. Andrei S. Correlations Between Antioxidant Enzymes Activity and Lipids Peroxidation Level in Blood and Milk from Cows with Subclinical Mastitis. Bull Univ Agric Sci Vet Med Cluj Napoca Vet Med. 2010; 67(1).

42. Xu B, Chang SKC. Isoflavones, Flavan-3-ols, Phenolic Acids, Total Phenolic Profiles, and Antioxidant Capacities of Soy Milk As Affected by Ultrahigh-Temperature and Traditional Processing Methods. J Agric Food Chem. 2009; 57(11): 4706-17. doi: 10.1021/jf900687j.

4. Mader JS, Salsman J, Conrad DM, Hoskin DW. Bovine lactoferricin selectively induces apoptosis in human leukemia and carcinoma cell lines. Mol Cancer Ther. 2005; 4(4): 612-24.

43. Amati L, Marzulli G, Martulli M, Tafaro A, Jirillo F, Pugliese V, et al. Donkey and Goat Milk Intake and Modulation of the Human Aged Immune. Curr Pharm Des. 2010; 16 (7): 864-9.

44. Alyaqoubi S, Abdullah A, Samudi M, Abdullah N, Addai ZR, Musa KH. Study of antioxidant activity and physicochemical properties of coconut milk (Pati santan) in Malaysia. J Chem Pharm Res. 2015; 7(4): 967-73.

45. Smet K, Raes K, De Block J, Herman L, Dewettinck $\mathrm{K}$, Coudijzer K. A change in antioxidative capacity as a measure of onset to oxidation in pasteurized milk. Int Dairy J. 2008; 18(5): 520-30. doi: 10.1016/j.idairyj.2007.11.012.

46. Zulueta A, Maurizi A, Frígola A, Esteve MJ, Coli R, Burini G. Antioxidant capacity of cow milk, whey and deproteinized milk. Int Dairy J. 2009; 19(6-7): 380-5. doi: 10.1016/j. 
idairyj.2009.02.003.

47. Chotyakul N, Pateiro-Moure M, Saraiva JA, Torres JA, Pérez-Lamela C. Simultaneous HPLC-DAD quantification of vitamins $\mathrm{A}$ and $\mathrm{E}$ content in raw, pasteurized, and UHT cow's milk and their changes during storage. Eur Food Res Technol. 2014; 238(4): 535-47.

48. Chen J, Gorton L, Åkesson B. Electrochemical studies on antioxidants in bovine milk. Anal Chim Acta. 2002; 474(1-2): 137-46.

49. Lipko-Przybylska J, Albera E, Kankofer M. Comparison of antioxidant defence parameters in colostrum and milk between Berrichon du Cher ewes and Uhrusk ewes. J Dairy Res. 2010; 77(1): 117-22.

50. Albera E, Kankofer M. The comparison of antioxidative/oxidative profile in blood, colostrum and milk of early post-partum cows and their newborns. Reprod Dom Anim 2011; 46(5): 763-9. doi: 10.1111/j.1439-0531.2010.01737.x.

51. Simos Y, Metsios A, Verginadis I, D’Alessandro A-G, Loiudice P, Jirillo E, et al. Antioxidant and anti-platelet properties of milk from goat, donkey and cow: An in vitro, ex vivo and in vivo study. Int Dairy J. 2011; 21(11): 901-6.

52. Ahmed AA-H, Saad NM, Wahba NM, Sayed RG. Nutritional Value and Antioxidant Activity of Camel's Milk. J Adv Vet Res. 2018; 8(4): 90-4.

53. Yigit A, Cinar M, Macun H, Ozenc E, Kabakci R, Yazici E, et al. Total oxidant and antioxidant activities in milk with various somatic cell count intervals during discrete cow and buffalo lactation periods. Indian J Dairy Sc1. 2018; 71(1): $72-7$.

54. Yuksel S, Yigit AA, Cinar M, Atmaca N, Onaran Y. Oxidant and antioxidant status of human breast milk during lactation period. Dairy Sci Technol. 2015; 95(3): 295-302.

55. Holbrook J, Hicks C. Variation of the superoxide dismutase in bovine milk. J Dairy Sc1. 1978; 61(8): 1072-77.

56. Nawito MF, Hameed ARAE, Sosa ASA, Mahmoud KGM. Impact of pregnancy and nutrition on oxidant/antioxidant balance in sheep and goats reared in South Sinai, Egypt. Vet World. 2016; 9(8): 801-5. doi: 10.14202/vetworld.2016.801-805.

57. Lindmark-Månsson $\mathrm{H}$, Åkesson B. Antioxidative factors in milk. Br J Nutr. 2000; 84(S1): 103-10. doi: 10.1017/ s0007114500002324.

58. Silvestre D, Miranda M, Muriach M, Almansa I, Jareño E, Romero FJ. Antioxidant capacity of human milk: effect of thermal conditions for the pasteurization. Acta Paediatr. 2008; 97(8): 1070-4. doi: 10.1111/j.1651-2227.2008.00870.x.

59. Debski B, Picciano M, Milner JA. Selenium content and distribution of human, cow and goat milk. J Nutr. 1987; 117(6): 1091-7. 